\title{
PEMERTAHANAN FONOLOGIS dan LEKSIKAL BAHASA JAWA di KABUPATEN WONOGIRI: KAJIAN GEOGRAFI DIALEK
}

\author{
Arif Antono ${ }^{\bowtie}$, Ida Zulaeha, Imam Baehaqie, \\ Jurusan Bahasa dan Sastra Indonesia, Fakultas Bahasa dan Seni, Universitas Negeri Semarang, \\ Indonesia
}

\begin{tabular}{l}
\hline Info Artikel \\
\hline Sejarah Artikel: \\
Diterima Januari 2019 \\
Disetujui Februari 2019 \\
Dipublikasikan Maret \\
2019
\end{tabular}

Keywords:

Phonological Defense, Lexical Defense, Dialectical Geography Dialog.

\begin{abstract}
Abstrak
Tujuan penelitian ini adalah untuk mendeskripsi wujud pemertahanan fonologis dan leksikal serta faktor-faktor yang turut memengaruhi pemertahanan tersebut berdasarkan tuturan dari pengguna bahasa Jawa di Kabupaten Wonogiri serta merujuk pada hasil penelusuran prabahasanya. Pendekatan penelitian ini menggunakan pendekatan deskriptif kualitatif. Data penelitian ini adalah leksikon serta sumber data penelitian ini adalah tuturan langsung dari informan atau pengguna bahasa Jawa di Kabupaten Wonogiri. Instrumen penelitian ini menggunakan 250 daftar tanyaan swadesh yang dikembangkan menjadi 755 tayaan. Pengumpulan data menggunakan metode simak dan cakap dengan teknik simak libat cakap, teknik rekam, dan teknik catat. Penggunaan metode cakap menggunakan teknik pancing dilanjukan dengan teknik cakap semuka, teknik rekam, dan teknik catat. Metode yang digunakan adalah metode padan. Analisis data menggunakan metode padan dengan tekniknya yaitu teknik pilah unsur penentu sebagai teknik dasar dan teknik hubung banding sebagai teknik lanjut. Dalam menelusuri prabahasa menggunakan metode rekontruksi induktif dengan teknik recontruction buttom up dan menggunakan metode rekontruksi deduktif dengan teknik recontruction top down. Hasil analisis disajikan dengan formal. Dalam BJW ditemukan wujud pemertahanan fonem vokal $/{ }^{*} \mathrm{i} /, /{ }^{*} \mathrm{u} /, /{ }^{*} \mathrm{\partial} /, /{ }^{*} \mathrm{O} /, /{ }^{*} \mathrm{a} /$, dan fonem konsonan $/{ }^{*} \mathrm{~b} /, /{ }^{*} \mathrm{c} /, /{ }^{*} \mathrm{~d} /, /{ }^{*} \mathrm{~g} /, /{ }^{*} \mathrm{k} /, /{ }^{*} \mathrm{j} /$, $/{ }^{*} \mathrm{~m} /, /{ }^{*} \mathrm{n} /, /{ }^{*} \mathrm{p} /, /{ }^{*} \mathrm{r} /, /{ }^{*} \mathrm{~s} /, /{ }^{*} \mathrm{t} /, /{ }^{*} \mathrm{w} /$, dan $/{ }^{*} \mathrm{y} /$. Pada tataran leksikon ditemukan 117 leksikon yang masih dipertahankan dari 18 medan makna. Faktor yang turut memengaruhi pemertahanan tersebut yakni faktor penutur, geografi, dan budaya.
\end{abstract}

\begin{abstract}
The purpose of this study is to describe the phonological and lexical forms of defense as well as the factors influencing the defense based on the speech of the Javanese language user in Wonogiri District and referring to the results of his pre-trial. This research approach using qualitative descriptive approach. The data of this research is lexicon and data source of this research is direct speech from informant or user of Java language in Wonogiri Regency. This research instrument uses 250 list of swadesh questionnaires developed into 755 celebrations. Collecting data using the method of referring and proficient with technically skilled involved, recording technique, and record technique. The use of skill method using the technique of fishing line is done with advanced skill technique, recording technique, and technique
\end{abstract}


of note. The method used is the method of match. Analysis of data using the method in combination with the technique that is the technique of decisive elements as the basic techniques and techniques of appeal as an advanced technique. In tracing the proto language using inductive reconstruction method with recontruction buttom up technique and using deductive reconstruction method with top down recontruction technique. The results of the analysis are presented formally. In BJW we find the vowel phoneme defense formation $/ *_{\mathrm{i}} /, / *^{*} \mathrm{u} /, / *^{*} /, / *_{\mathrm{o}} /, /{ }^{*} \mathrm{a} /$ and consonant phoneme $/{ }^{*} \mathrm{~b} /, /{ }^{*} \mathrm{c} /, /{ }^{*} \mathrm{~d} /, /{ }^{*} \mathrm{~g} /, /{ }^{*} \mathrm{k} /, /{ }^{*} \mathrm{j} /, /{ }^{*} \mathrm{~m} /, /{ }^{*} \mathrm{n} /, /{ }^{*} \mathrm{p} /, /{ }^{*} \mathrm{r} /, /{ }^{*} \mathrm{~s} /, /{ }^{*} \mathrm{t} /$, $/{ }^{*} \mathrm{w} /$, and $/{ }^{*} \mathrm{y} /$. At the level of lexicon found 117 lexicon that is still maintained. Factors contributing to the defense are speaker, geography, and cultural factors.

(C) 2019 Universitas Negeri Semarang

Alamat korespondensi:

Gedung B1 Lantai 1 FBS Unnes

ISSN 2252-6315

Kampus Sekaran, Gunungpati, Semarang, 50229

E-mail: arifantono18@gmail.com 


\section{PENDAHULUAN}

Bahasa merupakan salah satu fenomena sosial, Sukadaryanto dan Zulaeha (2005:1). Bahasa mengalami perubahan dari masa ke masa tidak terkecuali bahasa Jawa yang sampai saat ini dituturkan oleh penduduk di Jawa Tengah dan Jawa Timur sebagaimana dituturkan Zulaeha (2007:73) bahwa bahasa Jawa merupakan salah satu bahasa daerah di Indonesia yang jumlah pemakainya cukup besar, yaitu sekitar $50 \%$ dari seluruh penduduk Indonesia. Perubahan bahasa Jawa di suatu daerah tidak identik dengan perubahan yang terjadi di daerah lain, Sukadaryanto dan Zulaeha (2005:1). Untuk itu akan muncul variasi bahasa kedaerahan atau dialek seperti dialek Solo, dialek Yogyakarta, dialek Semarangan dan lain-lain yang memiliki ciri khas masing-masing dan cenderung berbeda ba hkan tidak ditemukan di daerah lain seperti dialek bahasa Jawa di Kabupaten Wonogiri. Secara tipologis masyarakat di Kabupaten Wonogiri dalam penggunaan bahasanya lugas, spontan dan menggunakan bahasa Jawa ngoko. Oleh karena itu bahasa Jawa di Kabupaten Wonogiri akan memperlihatkan adanya wujud pemertahanan dialek yang sangat menarik untuk diteliti berdasarkan faktor geografis. Berdasarkan pengamatan awal yang telah dilakukan, data yang ditemukan sebagai wujud pemertahanan bahasa Jawa di Kabupaten Wonogiri yaitu pada gloss 'dagu' < PMJ [d'annut] dalam BJW [JangUt], gloss 'ketiak' <PAN [kilik] dalam BJW [kələk]. Dari data pengamatan awal tersebut leksikon ini merupakan refleks yang dipantulkan secara langsung ke proto dan merupakan eviden yang identik dari etimon prabahasanya sebagai unsur retensi. Pemertahanan dialek bahasa Jawa di Kabupaten Wonogiri ini penting dan menarik untuk diteliti karena mengingat penelitian ini akan memberikan gambaran yang objektif tentang bagaimana wujud pemertahanan dialek BJW dan faktor-faktor apa sajakan yang memengaruhi pemertahanan BJW tersebut serta akan dapat diketahui bahwa BJW merupakan daerah yang konservatif atau inovatif.

\section{Rumusan Masalah}

Dari paparan tersebut, rumusan masalahnya adalah sebagai berikut.

1) Bagaimanakah wujud pemertahanan bahasa Jawa di Kabupaten Wonogiri pada tataran fonologis?

2) Bagaimanakah wujud pemertahanan bahasa Jawa di Kabupaten Wonogiri pada tataran leksikal?

3) Apa sajakah faktor-faktor yang memengaruhi pemertahanan bahasa Jawa di Kabupaten Wonogiri?

\section{Tujuan Penelitian}

Berkaitan dengan rumusan masalah tersebut, tujuan penelitian ini adalah sebagai berikut.

1) mendeskripsi wujud pemertahanan bahasa Jawa di Kabupaten Wonogiri pada tataran fonologis;

2) mendeskripsi wujud pemertahanan dialek bahasa Jawa di Kabupaten Wonogiri pada tataran leksikal; serta

3) mendeskripsi faktor-faktor yang memengaruhi pemertahanan fonologis dan leksikal bahasa Jawa di Kabupaten Wonogiri.

\section{Manfaat Penelitian}

Dalam penelitian ini akan dipaparkan manfaatnya yang tediri atas dua manfaat yaitu manfaat teoretis dan manfaat praktis.

1) Manfaat Teoretis

Manfaat secara teoretis dari penelitian ini yaitu sebagai bahan referensi dalam mengembangkan teori-teori ilmu dialektologi dan dapat dijadikan sebagai bahan untuk menambah wawasan dalam ilmu kebahasaan khususnya pada pemertahanan fonologis dan leksikal.

2) Manfaat Praktis

Manfaat praktisnya yaitu untuk para peneliti dialektologi hasil ini dapat digunakan sebagai rujukan untuk kajian-kajian selanjutnya. Untuk pemerintah kabupaten wonogiri, hasil ini dapat dijadikan sebagai bahan untuk melengkapi data administratif dan sebagai daftar penentuan terhadap kabupaten wonogiri sebagai daerah inovatif atau konservatif.

\section{Landasan Teoretis}

\section{Perspektif Dialek Geografi Diakronis}

Geografi dialek memelajari hubungan yang terdapat di dalam ragam-ragam bahasa yang bertumpu kepada satuan ruang atau tempat terwujudnya ragam-ragam itu. Geografi dialek berhubungan erat dengan ilmu bahasa bandingan yang dikenal sebagai linguistik historis komparatif. Perlu ditekankan bahwa lahirnya dialektologi adalah perkembangan kajian linguistik historis komparatif, Mahsun (1995:5). Berdasarkan hal tersebut, tidak dapat dipungkiri bahwa kajian linguistik historis komparattf memiliki andil dalam kajian dialektologi diakronis khususnya yang berkaitan dengan pemanfaatan metode linguistik historis komparatif seperti dalam rekontruksi prabahasa, penelusuran unsur inovasi, dan relik.

Istilah diakronis berkenaan dengan pendekatan terhadap bahasa dengan melihat perkembangannya sepanjang waktu, jadi bersifat historis, (Saussure dan Kridalaksana dalam 
Mahsun 1995:12). Berpijak dari pengertian tersebut, maka untuk menentukan pemertahanan sebuah bahasa haruslah mencari bentuk relik prabahasanya, sebagaimana diungkapkan oleh Mahsun (1995:12) bahwa secara diakronis pembicaraan tentang dialek/subdialek adalah pembicaraan tentang "bagaimana" eksistensi pembicaraan dialek/subdialek itu. Berdasarkan uraian tersebut, Mahsun (1995:13) menyimpulkan bahwa yang dimaksud dengan dialektologi diakronis adalah suatu kajian tentang perbedaan-perbedaan isolek yang bersifat analitis sinkronis dengan penafsiran perbedaanperbedaan isolek tersebut berdasarkan kajian historis dan diakronis.

\section{Perbedaan Unsur-Unsur Kebahasaan}

Linguistik merupakan ilmu yang mengkaji tentang unsur-unsur kebahasaan seperti fonologi, morfologi, sintaksis, leksikon, dan semantik. Semua unsur kebahasaan tersebut dapat dikaji di dalam kajian ilmu dialektologi. Namun, penelitian ini hanya akan fokus pada tataran fonologi dan leksikon.

\section{Perbedaan Fonologis}

Fonologi merupakan ilmu yang memelajari bunyi bahasa sebagai satuan bahasa terkecil yang memiliki fungsi pembeda, Sasangka (2011:1). Fonologi mengkaji dan menganalisis pemanfaatan bunyi bahasa dan sistem bunyi bahasa untuk mengontraskan ciri-ciri bunyi yang terdapat dalam suatu bahasa. Yang dimaksud perbedaan fonologi dalam kajian linguistik kali ini menyangkut perbedaan fonetik. Hal ini ditegaskan oleh Ayatrohaedi (dalam Mahsun, 1995:23) bahwa perbedaan fonologi perlu dibedakan dengan perbedaan leksikon mengingat dalam proses penentuan isolek sebagai bahasa, dialek, atau subdialek dengan menggunakan dialektometri pada tataran leksikon, perbedaanperbedaan fonologi yang muncul dianggap tidak ada. Menurut Mahsun, (1995:24) pada prinsipnya, perbedaan-perbedaan yang terdapat pada leksem-leksem yang menyatakan makna yang sama itu dianggap sebagai perbedaan fonologi jika leksem-leksem itu diturunkan dari satu etimon prabahasa/protobahasa yang sama. Oleh karena itu apabila di samping perbedaan yang berupa korespondensi atau variasi terdapat refleks etimon lain yang digunakan untuk menyatakan makna tersebut, maka dalam kondisi yang semacam itu terdapat perbedaan dalam dua bidang linguistik sekaligus, yaitu fonologi dan leksikon.

Perbedaan fonologi yang terjadi di antara daerah-daerah pengamatan atau di antara bahasabahasa muncul sebagai akibat dari perbedaan dalam merefleksikan prafonem / protofonem yang terdapat pada prabahasa / protobahasa. Pewarisan bentuk-bentuk yang terdapat pada prabahasa/protobahasa ada yang linear dan tidak linear. Berbeda dengan pewarisan yang bersifat linear, pada pewarisan yang tidak linear fonem bentuk prabahasa / protobahasa yang mengalami perubahan itu sulit ditemukan keteraturan/rekuresinya. Hal ini berkaitan dengan inovasi dan retensi / pemertahanan yang terjadi pada tahapan perkembangan tertentu. Pewarisan dalam bentuk-bentuk prabahasa / protobahasa yang terdapat pada dialek / subdialek atau bahasa-bahasa turunannya pada dasarnya memiliki dua pola yaitu retensi dan inovasi. Pola pewarisan yang berupa retensi / pemertahanan yaitu pewarisan prafonem atau protofonem suatu prabahasa / protobahasa sebagaimana adanya dalam dialek/subdialek atau bahasa-bahasa turunannya, Mahsun (1995:25)

\section{Perbedaan Leksikon}

Leksikon merupakan komponen bahasa yang memuat semua informasi tentang makna dan pemakaian kata dalam suatu bahasa informasi tentang makna dan pemakaian kata dalam suatu bahasa, Kridalaksana (dalam sasongko, 2004:25). Selain itu leksikon juga merupakan kekayaan kata yang dimiliki suatu bahasa. Menurut Mahsun (1995:54) suatu perbedaan disebut sebagai perbedaan dalam bidang leksikon, jika leksem-leksem yang digunakan untuk merealisasikan suatu makna yang sama tidak berasal dari satu etimon prabahasa. Lebih jelasnya, bahwa sebuah leksem apabila masih mengalami kemiripan bentuk dan makna sama dari prabahasa/protobahasanya, maka leksem tersebut dapat dikategorikan sebagai wujud pemertahanan leksikon. Namun jika tidak, maka leksem tersebut sudah mengalami pergeseran bahasa/mengalami inovasi. Kategori-kategori tersebut terbagi atas empat bentuk yaitu 1) Leksikon Bentuk Sama Makna Sama yaitu leksikon yang bentuknya sama persis/identik dan maknanyasama persis. 2) Leksikon Bentuk Sama Makna Berbeda, yaitu kata yang bentuknya sama (bentuk sama persis) tetapi memiliki perbedaan dalam makna, 3) Leksikon Bentuk Berbeda Makna Sama, yaitu kata yang berbeda sama sekali tetapi memiliki makna yang sama. 4) Leksikon Bentuk Mirip Makna Sama, menurut Mahsun (2014:214) leksikon bentuk mirip makna sama adalah kata yang sama maknanya, tetapi terdapat perbedaan pada bentuk di satu atau dua bunyi yang posisinya sama. 5) Leksikon Bentuk Mirip Makna Berbeda yaitu kata yang memiliki perbedaan 
makna serta terdapat perbedaan pada bentuk di satu atau dua bunyi yang posisinya sama.

\section{Pemertahanan dan Pergeseran Dialek}

Bahasa itu bersifat dinamis, Chaer dan Agustina (1995:17) maksudnya bahasa itu tidak terlepas dari berbagai kemungkinan perubahan yang sewaktu-waktu dapat terjadi. Perubahan itu dapat terjadi pada tataran apa saja: fonologi, morfologi, sintaksis, semantik, dan leksikon. Selain dinamis, bahasa juga bersifat beragam, Chaer dan Agustina (1995:18) artinya meskipun sebuah bahasa mempunyai kaidah atau pola tertentu yang sama, namun karena bahasa tu digunakan oleh penutur yang heterogen yang mempunyai latar belakang sosial dan kebiasaan yang berbeda maka bahasa itu menjadi beragam, baik dalam tataran fonologi, morfologi, sintaksis, semantik, dan leksikon. Penggunaan bahasa Jawa. Oleh penutur bahasa Jawa di setiap daerah akan berbeda. Hal ini terjadi karena sosiokultur yang berbeda, cara hidup yang berbeda, dan cara berkomunikasi yang berbeda. Dalam konteks masyarakat yang heterogen, kontak budaya, dan kontak bahasa, ini akan memungkinkan sebuah bahasa/dialek akan mengalami pergeseran. Daerah yang konservatif akan memertahankan bahasanya, sedang derah yang inovtif akan mengalami pergeseran bahasa/dialek.

\section{Faktor-Faktor Yang Mempengaruhi Pemertahanan Dialek}

Menurut Sukadaryanto dan Zulaeha (2005:8) faktor-faktor yang turut memengaruhi pemertahanan dialek yaitu faktor sosial, budaya, dan situasional. Berkait dengan faktor sosial seperti pendidikan, pekerjaan, dan status soaial sangat memengaruhi sebuah dialek. Hal ini ditekankan oleh Zulaeha (2010:24) bahwa seiring dengan semakin membaiknya taraf sosialekonomi masyarakat semakin membaik pula taraf pendidikan masyarakat. pada umumnya mereka meninggalkan kampung halamannya untuk mencari ilmu atau bekerja, seperti; pedagang, buruh, pegawai daerah, dan sebagainya. Setiap pagi mereka datang ke kota dan sorenya mereka kembali ke kampung bagi pekerja dan mobilitas sirkulasi. Sementara para mahasiswa (orang yang belajar di perguruan tinggi) dari kampung itu merasa malu ketika menggunakan dialek di daerahnya. Mereka cenderung meggunakan bahasa yang dianggapnya berprestise dalam pergaulan sehari-hari. Kebiasaan itu juga dilakukan dalam berbahasa sehari-hari ketika mereka kembali ke kampung halaman. Kebiasaan itu kemudian diikuti oleh kelompoknya dan masyarakat di lingkungannya karena mereka dianggap sebagai orang berpengalaman. Dari pernyataan tersebut dapat disimpulkan bahwa faktor sosial sangat memengaruhi atas pemertahanan sebuah dialek. Pendidikan sangat memengaruhi cara berpikir seseorang termasuk penggunaan bahasa.

Faktor lain yang memengaruhi pemertahanan dialek adalah faktor budaya. Perlu ditekankan bahwa bahasa adalah bagian dari tujuh unsur kebudayaan sebagaimana diungkapkan oleh koentjaraningrat (1997:2) tujuh unsur kebudayaan secara universal antara lain; 1 ) sistem religi dan upacara keagamaan, 2) sistem dan organisasi kemasyarakatan, 3) sistem pengetahuan, 4) bahasa, 5) kesenian, 6) sistem mata pencaharian hidup, dan 7) sistem teknologi dan peralatan. Dari ketujuh unsur tersebut dapat dilihat bahwa semuanya saling berkaitan dan berpotensi menentukan pemertahanan dialek. $\mathrm{Hal}$ ini dapat dibuktikan dengan cara hidup dari mata pencaharian. Masyarakat yang mata pencahariannya sebagai nelayan dan tinggal di dataran rendah, mereka cenderung menggunakan nada tinggi dalam berbicara. Hal ini dikarenakan para nelayan harus dapat bersuara lebih keras dibandingkan dengan ombak. Jadi, dalam masyarakat nelayan, berbicara dengan nada tinggi tidak berarti dia sedang marah. Hal ini akan bertolak belakang dengan kehidupan di wilayah pegunungan. Masyarakat yang tinggal di dataran tinggi dan berprofesi sebagai petani tidak harus menggunakan nada tinggi dalam berbicara. Hal ini dikarenakan kondisi atau ketak geografisnya yang mendukung mereka tidak harus menggunakan nada tinggi dalam berbicara. Mereka menggunakan nada tinggi hanya saat mereka marah. Seperti umumnya masyarakat di jawa.

\section{Metodologi Penelitian}

Pengumpulan data menggunakan metode simak dan cakap dengan teknik simak libat cakap, teknik rekam, dan teknik catat. Penggunaan metode cakap menggunakan teknik pancing dilanjukan dengan teknik cakap semuka, teknik rekam, dan teknik catat. Metode yang digunakan adalah metode padan. Analisis data menggunakan metode padan dengan tekniknya yaitu teknik pilah unsur penentu sebagai teknik dasar dan teknik hubung banding sebagai teknik lanjut. Dalam menelusuri prabahasa menggunakan metode rekontruksi induktif dengan teknik recontruction buttom up dan menggunakan metode rekontruksi deduktif dengan teknik recontruction top down.

\section{PEMBAHASAN}

\section{Pemertahanan Fonologis}

Pemertahanan fonologis yang terlihat dalam BJW terdapat dalam kosakata yang didasarkan pada reflek-reflek yang ditemui di semua titik pengamatan. Pemertahanan fonologis 
ini muncul sebagai retensi pada titik pengamatan. Wujud pemertahanan fonologis tersebut akan diurai sebagai berikut.

1. Fonem vokal depan tinggi $/ *^{*} /$

a. $\mathrm{BJW} /{ }^{*} \mathrm{i} /(<\mathrm{PAN} / \mathrm{PMJ}) / \# \mathrm{IK}-: 166$

Berdasarkan data yang diperoleh dalam pemakaian BJW ditemukan adanya pemertahanan fonologis prafonem vokal pada beberapa

bentuk leksikon, seperti tampak pada data berikut.

\section{PAN/PMJ BJW Gloss No. Data} *kulIt (PAN) [kulIt] 'kulit' 166

Berdasarkan data tersebut gloss 'kulit' dalam BJW dituturkan [kulIt] dan dari hasil penelusuran prabahasanya gloss 'kulit' merujuk pada proto PAN *kulIt. Dari data tersebut glos ini tidak mengalami perubahan bunyi sedikitpun karena BJW masih mempertahanan fonem vokal /*I/ sebagai retensi prafonem.

b. $\mathrm{BJW} / *_{\mathrm{i}} /(<\mathrm{PAN} / \mathrm{PMJ}) /-\mathrm{Ki} \#: 032$

Berdasarkan data yang diperoleh dalam pemakaian BJW ditemukan adanya pemertahanan fonologis prafonem vokal pada beberapa bentuk leksikon, seperti tampak pada data berikut.

PAN/PMJ BJW Gloss No. *bəRni(PANC) [woni] 'malam' 032 TP 1

[bəni]

TP 2 dan

TP 3

Berdasarkan data tersebut gloss 'malam' dalam BJW dituturkan [wəri] di TP 1 dan dituturkan [bəyi] di TP 2 dan TP 3. Dari hasil penelusuran prabahasanya gloss 'malam' merujuk pada proto PANC *bəRni. Dari data tersebut BJW masih memertahankan fonem vokal $/ *_{\mathrm{i}}$ / pada posisi ultima sebagai retensi unsur relik yang merupakan wujud pewarisan berupa pelesapan, yakni fonem /R/ dalam PANC melesap. Dari data tersebut pula, setelah ditelusuri menggunakan metode buttom up, ditemukan adanya pemertahanan fonologis yang merupakan unsur relik dari prabahasanya, dapat dilihat dalam analisis berikut.

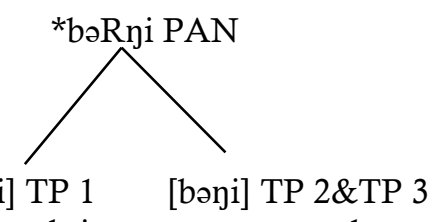

Dalam rekonstruksi yang menggunakan metode buttom up tersebut terdapat variasi bunyi di masingmasing TP yakni bunyi konsonan pada posisi awal di TP1 dituturkan dengan konsonan /w/ sedang TP 2 \& TP 3 dituturkan dengan konsonan /b/ sehingga konsonan /b/ inilah yang merupakan konsonan tuanya.

2. Fonem vokal belakang tinggi $/{ }^{*} \mathrm{u} /$

a. BJW $/ * \mathrm{U} /(<\mathrm{PAN} / \mathrm{PMJ}) /-\mathrm{KU} \#: 008$

Berdasarkan data yang diperoleh dalam pemakaian BJW ditemukan adanya pemertahanan fonologis prafonem vokal pada beberapa bentuk leksikon, seperti tampak pada data berikut.

\section{PAN/PMJ BJW Gloss No. Data *walU (PAN) [w ${ }^{\text {h }}$ 1 lu] 'delapan' 008}

Berdasarkan data 008 pada Gloss 'delapan' dalam BJW dituturkan [ $w^{\text {h }}$ Jlu] dan dari hasil penelusuran prabahasanya gloss 'delapan' merujuk pada proto PANC [*walU]. Dari data tersebut nampak bahwa BJW masih mempertahankan fonem vokal /*U/ sebagai retensi unsur relik bahasa protonya. Dalam data 008 ini terdapat temuan berupa korespondensi bunyi /a/ "/J/ karena mengalami proses asimilasi regresif pada ultima.

3. Fonem vokal setengah tertutup $/ *^{*} /$

a. BJW /*a/ (PAN/PMJ) /\#əK- :232

Berdasarkan data yang diperoleh dalam pemakaian BJW ditemukan adanya pemertahanan fonologis fonem vokal pada beberapa bentuk leksikon, seperti tampak pada data berikut,

\section{PAN/PMJ BJW Gloss No. Data}

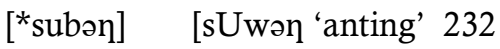

Berdasarkan data 232 pada gloss 'anting' dalam BJW dituturkan [sUwə⿱] dan dari hasil penelusuran prabahasanya gloss 'anting' merujuk pada proto PAND [*subən]. Dari data tersebut terjadi korespondensi /b/ " /W/ dan BJW masih mempertahankan fonem vokal /ə/ sebagai retensi unsur relik bahasanya.

4. Fonem Vokal Belakang Setengah Tertutup $/{ }^{*} \mathrm{O} /$

a. $\mathrm{BJW} /{ }^{*} \mathrm{O} /(\mathrm{PAN} / \mathrm{PMJ}) / \# \mathrm{Ko}-152$

Berdasarkan data yang diperoleh dalam pemakaian BJW ditemukan 
yang dipantulkan secara langsung ke proto dan merupakan eviden yang mirip dari etimon prabahasanya sebagai unsur retensi.

\section{Gloss BJW Prabahasa No Data}

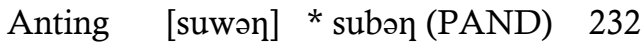

Pada tabel tersebut data 232, gloss 'anting' dalam BJW dituturkan [sUwə⿱] dan dari hasil penelusuran prabahasanya gloss 'anting' merupakan cerminan dari proto PAND *subən. Dari data tersebut, bentuk leksikon ini merupakan refleks yang dipantulkan secara langsung ke proto dan merupakan eviden yang mirip dari etimon prabahasanya sebagai unsur retensi.

\section{Gloss BJW Prabahasa No Data}

Belalang [walan] *balan (PAND) 283

Pada tabel tersebut data 283, gloss 'belalang' dalam BJW dituturkan /walan/ dan dari hasil penelusuran prabahasanya gloss 'belalang' merupakan cerminan dari proto PAND *balan. Dari data tersebut, bentuk leksikon ini merupakan refleks yang dipantulkan secara langsung ke proto dan merupakan eviden yang mirip dari etimon prabahasanya sebagai unsur retensi.

\section{Faktor-faktor Penyebab Pemertahanan Fonologis dan Leksikal Bahasa Jawa di Kabupaten Wonogiri}

Dalam penggunaan bahasa sehari-hari di Kabupaten Wonogiri memperlihatkan adanya bentuk pemertahanan bahasa pada tataran fonologis dan leksikon. Pemertahanan ini tidak terlepas dari faktor-faktor yang turut memengaruhinya. Adapun faktor-faktor yang turut memengaruhi pemertahanan fonologis dan leksikon adalah sebagai berikut.

\section{Faktor Penutur}

Faktor penutur merupakan faktor yang turut memengaruhi pemertahanan fonologis dan leksikal. Dilihat dari kelas sosial, penutur berpendidikan rendah dan berusia tua cenderung melakukan pemertahanan. Sedangkan penutur berpendidikan tinggi dan berusia muda cenderung melakukan perubahan. Hal ini tampak dalam gloss 'putih'. Dalam glos ini penutur yang berpendidikan rendah dan berusia tua cenderung menuturkannya [putch] dan penutur yang berpendidikan tinggi dan berusia muda cenderung menuturkan [putih]. Pemertahanan leksikon dilakukan oleh penutur yang berpendidikan rendah dia berusia tua. Seperti tampak dalam glos 'anting' penutur berpendidikan rendah dan berusia tua

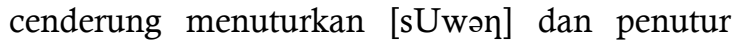
berpendidikan tinggi cenderung menuturkan [antIn]. Hal berikut terjadi karena penutur berpendidikan rendah dan berusia tua mobilitasnya rendah dan bahasa yang dituturkannya mencerminkan unsur relik.

\section{Faktor Geografis}

Daerah di Kabupaten Wonogiri apabila dilihat dari segi geografisnya , berada $32 \mathrm{~km}$ di sebelah selatan Kota Solo, berbatasan dengan Provinsi Jawa Timur di sebelah timur, dan Daerah Istimewa Yogyakarta di sebelah barat. Masyarakat Kabupaten Wonogiri secara geografis menempati wilayah yang diapit oleh beberapa dialek seperti dialek DIY, dialek Jawatimuran, dan dialek Surakarta. Karena lokasi yang berbatasan, memungkinkan adanya kontak bahasa dan kontak budaya yang dapat memengaruhi bahasa Jawa Kabupaten Wonogiri. Dari asumsi itulah BJW tidak semua TP melakukan pemertahanan. TP yang melakukan pemertahanan adalah daerah yang mobilitasnya rendah seperti di TP 2 dan 3. Daerah ini cenderung memertahankan unsur relik dibanding TP 1. Hal ini terjadi karena TP 1 merupakan daerah yang paling dekat dengan pusat kota. Sehingga akan mengalami banyak inovasi karena banyak penutur yang berpendidikan tinggi.

\section{Faktor Budaya}

Budaya merupakan salah satu faktor yang turut memengaruhi pemertahanan dialek di Kabupaten Wonogiri. Dilihat dari nilai kesantunan dan kesopanan dalam berbahasa, masyarakat di TP 3 dalam bertutur cenderung egaliter dalam bertutur. Hal ini berlaku kepada diri sendiri, teman sebaya dan orang semestinya dihormati seperti orang tua. Namun, jika bertutur dengan orang terpandang atau seorang priyayi, mereka cenderung menggunakan bahasa yang santun seperti krama. Hal ini berbeda dengan masyarakat di TP 1 dan TP 2. Cara bertutur mereka cenderung menggunakan kaidah yang semestinya, yaitu berbicara spontan dan santun ketika berbicara dengan orang yang semestinya dihormati.

\section{PENUTUP \\ Simpulan}

Berdasarkan hasil analisis tentang pemertahanan fonologis dan leksikon bahasa Jawa di Kabupaten Wonogiri serta faktor-faktor yang memengaruhinya, dapat disimpulkan sebagai berikut.

1. Pemertahanan fonologis yang terdapat di BJW berwujud temuan asli atau berupa unsur relik dari prabahasanya baik dari PAN maupun PMJ. Hal ini diperkuat dengan ditemukannnya wujud pemertahanan fonem vokal $/ * \mathrm{I} /, / * \mathrm{U} /$, $/ *^{*} /, / *_{0} /$, dan $/ *_{a} /$, dan fonem konsonan $/{ }^{*} \mathrm{~b} /, /{ }^{*} \mathrm{c} /, /{ }^{*} \mathrm{~d} /, /{ }^{*} \mathrm{~g} /, /{ }^{*} \mathrm{k} /$, $/{ }^{*} \mathrm{j} /, /{ }^{*} \mathrm{~m} /, /{ }^{*} \mathrm{n} /, /{ }^{*} \mathrm{p} /, /{ }^{*} \mathrm{r} /, /{ }^{*} \mathrm{~s} /, / *^{*} /$, $/{ }^{*} \mathrm{w} /$, dan $/{ }^{*} \mathrm{y} /$. 
2. Pemertahanan leksikon yang terdapat dalam BJW berwujud unsur relik dari etimon prabahasanya yang menampakkan unsur keaslian dan kemiripan. Dari hasil kajian ini ditemukan sebanyak 117 leksikon dari 18 medan makna yang masih dipertahankan dari total 755 leksikon. Jadi prosentasenya adalah $(117: 755) \mathrm{x}$ $100 \%=15 \%$.

3. Faktor-faktor yang turut memengaruhi pemertahanan BJW antara lain, a) faktor penutur melingkupi kelas sosial baik pendidikan, pekerjaan maupun usia penutur, b) faktor geografis melingkupi letak Kabupaten Wonogiri yang berdampingan dengan daerah-daerah tetangga yang berbeda dialek yang turut serta memengaruhi dialek asli BJW, dan c) faktor budaya yang melingkupi pola hidup, perkembangan zaman, tingkat Saran mobilitas, dan karakter masyarakatnya.

Hasil dari penelitian ini merupakan unsur relik atau temuan asli prabahasa yang digunakan masyarakat di Kabupaten Wonogiri yang sudah dipetakkan wujud pemertahanannya pada tataran fonologis, tataran leksikon, dan diungkapkan pula faktor-faktor yang turut memengaruhi pemertahanannya. Walau sudah demikian, penelitian tentang ini perlu ditindaklanjuti secara mendalam agar muncul temuan-temuan baru yang akan dikembangkan mengingat bahwa sebuah kajian itu akan terus berkembang. Dari segi instrumen penelitian yang berjumlah 755 kosakata, maka akan menarik jika dilakukan penelitian lanjut dengan jumlah kosakata yang banyak lagi sehingga akan lebih bisa membuktikan bahwa bahasa yang digunakan oleh masyarakat di Kabupaten Wonogiri termasuk bahasa yang konservatif atau inovatif.

\section{DAFTAR PUSTAKA}

Adelaar, K. Alexander. 1994. Bahasa Melayik Purba. Jakarta: Pusat Pembinaan dan Pengembangan Bahasa dan Universitas Leiden.

Arifudin. 2015. "Bahasa Jawa di Kabupaten Kebumen(Kajian Sosiodialektologi)". Skripsi Semarang: Unnes.

Atmawati, Dwi. 2014. "Refleks Fonem-Fonem Proto Malayo-Polynesian (PMP) terhadap Bahasa Rejang”. Journal. Vol. 20, No. 03, 2014. Balai Bahasa Provinsi Jawa Tengah: Semarang

Aurrekoetxea, Gotzon. 2013. "DiaTech: A New Tool for Dialectology". Journal. Vol. 28, No. 1, 2013. Department of
Linguistics and Basque Studies, University of the Basque Country (UPV/EHU), Spain.

Chaer, Abdul dan Leonie Agustina. 1995. Sosiolinguistik Suatu Pengantar. Jakarta: Rineka Cipta.

Keraf, Gorys. 1996. Linguistik Bandingan Historis. Jakarta:Gramedia.

Kurniawati, Asih. (2013) "Bentuk Fonologi dan Leksikon Dialek Bahasa Jawa Desa

Jogopaten Kecamatan Buluspesantren Kabupaten Kebumen". Journal Vol. 03 / No. 02/November 2013. Universitas Muhammadiyah Purwokerto.

Kretzschmar, William A. 2006. "Art and Science in Computational Dialectology". Journal. Vol. 21, No. 4, $2006 . \mathrm{Jr}$ University of Georgia, Athens, GA, USA

Kusworo, Heri. 2013. "Kajian Dialek Bahasa Jawa di Desa Muktisari Kecamatan Kebumen Kabupaten Kebumen". Journal. Universitas Muhammadiyah Purwokerto.

Markus, Manfred. 2012. "English Dialect Dictionary and Beyond". Journal. Vol. 25 No. 2, 2012. Frankfurt am Main, Berlin, Bern, Bruxelles, NewYork.

Patriantoro. 2016. "Rekontruksi Fonologi Bahasa Melayu di Kabupaten Mempawah dan Sambas" Journal Magistra No. 95 Th XXVIII 2016. Pontianak: Universitas Tanjungpura Pontianak.

Rahayu, Ika Mamik. 2011. "Variasi Dialek Bahasa Jawa di Wilayah Kabupaten Ngawi: Kajian Dialektologi" Journal.

Sasangka, Sry Satya T W. Bunyi-Bunyi Distingtif Bahasa Jawa. Yogyakarta: Elmatera Publishing.

Sasongko, Hasto Aji. 2015. "Variasi Leksikal Bahasa Jawa Ngoko Masyarakat Desa Ngadirejo Kecamatan Reban Kabupaten Batang" skripsi. Semarang: Unnes.

Ibarani, Robert. 2004. Antropolinguistik. Medan: Penerbit Poda.

Sudaryanto. 2015. Metode dan Aneka Teknik Analisis Bahasa. Yogyakarta: Sanata Dharma University Press.

Sukadaryanto dan Ida Zulaeha. 2005. Pemertahanan Dialek Bahasa Jawa di Wilayah Pesisir Utara (Kajian Geografi Dialek di Kabupaten Pati). Laporan Penelitian Universitas Negeri Semarang

Suwadji, dkk. 1981. Struktur Dialek Bahasa Jawa di Pesisir Utara Jawa Tengah 9Tegal dan Sekitarnta). Jakarta: Pusat Pembinaan dan Pengembangan Bahasa Departemen Pendidikan dan Kebudayaan. 
Wiladati, Ribka Adresti. 2014. "Bahasa Jawa di Kabupaten Batang (Tataran Fonologi dan Leksikal)". Journal of Javanesse Literature. Sutasoma.

Wurm, S. A. dan B. Wilson. 1978. English Finderlist Of Recontructions In Austronesian Languages (Post-Brandstetter).Canberra: The Australian National Univercity.

Yudhibrata, Karna, dkk. 1990. Geografi Dialek Bahasa Sunda di Kabupaten Karawang.
Jakarta: Departemen Pendidikan dan Kebudayaan.

Zulaeha, Ida. 2001. "Pemakaian Bahasa Jawa di Kabupaten Semarang: Kajian Sosiodialektologi". Tesis. Yogyakarta: UGM. Zulaeha, Ida. 2010. Dialektologi (Dialek Geografi dan Dialek Sosial). Yogyakarta: Graha Ilmu. 